\title{
Consensus
}

Volume 31

Issue 2 Faith, Freedom, and the Academy

Article 18

$11-1-2006$

\section{Introducing the Old Testament}

Roger W. Uitti

Follow this and additional works at: http://scholars.wlu.ca/consensus

\section{Recommended Citation}

Uitti, Roger W. (2006) "Introducing the Old Testament, ," Consensus: Vol. 31 : Iss. 2 , Article 18.

Available at: http://scholars.wlu.ca/consensus/vol31/iss2/18

This Book Reviews is brought to you for free and open access by Scholars Commons @ Laurier. It has been accepted for inclusion in Consensus by an authorized editor of Scholars Commons @ Laurier. For more information, please contact scholarscommons@wlu.ca. 
one does not speak explicitly in political terms. The vital question is, Whose politics and ideology gets advanced - ours or God's? A new third edition might also render the transcription of Hebrew words into their English equivalents more precisely. Kudos to the editor: I noted only two typos: "Genesis 12-60" (p. 54) and "Ancient Near East" (pp. $21 \mathrm{ff}$.$) .$

Roger W. Uitti,

Professor of Old Testament emeritus

Lutheran Theological Seminary, Saskatoon

\section{Introducing the Old Testament}

Richard J. Coggins

The Oxford Bible Series, edited by P.R. Ackroyd and G.N. Stanton. New York, NY: Oxford University Press, 1990; second revised edition, May 2001

$165 / 176$ pages, $\$ 35.00$ Softcover

Reverend Richard Coggins is now retired and was formerly Senior Lecturer in Old Testament Studies at King's College London. In all, there are nine volumes published so far in the Oxford Bible Series. Two of the volumes provide general orientation, one is devoted to the cultural and historical context of the Old Testament, the second deals with the New Testament, treating the origins of Christianity. Four other volumes deal with the main literatures of the Old Testament: narrative, prophecy, poetry/psalmody, and wisdom/law. Two New Testament volumes discuss Paul and Pauline Christianity and the variety and unity of New Testament thought. The nature of biblical interpretation is given over to the ninth and last volume in the series.

This present work is the first one cited above, an introduction to the environment of the Old Testament. Like the other volumes in the series this short book is designed to stand on its own, providing a helpful background for subsequent study. The format of chapters is a series of questions. What is the Old Testament? What Does It Mean? Did It All Happen? What Does Archeology Contribute? What Kind of Society Was Israel? What Is Man? The Old Testament as Liberation? (The $2^{\text {nd }}$ rev. ed. of 176 pages divides the 1990 chapter into two 
question chapters: The OT as Liberation? and Can the Bible Speak to Women?) What Kind of Literature? What Kind of Religion? Is a Theology Possible? This listing of questions shows that this book is not an introduction to the individual books or canon of the Old Testament/Hebrew Bible per se but to its world. It addresses the question of the inadequacies of the historical-critical method and explores the contributions of both liberation/feminist and new style literary approaches. The final quest is on what a volume on OT theology should contain and suggests an organization of thought under four points: (a) affirmations in the OT about the nature of God; (b) concern in the OT for community rather than individual values; (c) the character of the prophetic critique of a nominally religious society; and (d) tolerance within the OT for more radical skepticism alongside normative revered tradition.

The volume is written for a general readership. Quotations are from the RSV. Technical terms and Hebrew/Greek words cited are explained. Specific points are meaningfully supported through an analysis of selected Old Testament passages. The paperback closes with a brief bibliography, an index of passages cited, and a general index. While somewhat dated, the book does offer some noteworthy insights.

Roger W. Uitti

Professor of Old Testament emeritus

Lutheran Theological Seminary, Saskatoon

\section{Introduction to the Hebrew Bible with CD-ROM John J. Collins \\ Minneapolis: Fortress Press, 2004 \\ 613 pages, $\$ 49.00$ Softcover}

John J. Collins, the author of this Hebrew Bible/OT Introduction, is an accomplished scholar of Roman Catholic background and teaching, and former president of the Catholic Biblical Association and the Society of Biblical Literature. He has been a professor at a number of prestigious universities (U. of Chicago, Notre Dame, and now Yale). He is well known for his work in Hellenistic Judaism and 